\title{
Evaluation of Clinicopathological Findings and Postoperative Outcomes of Modified Radical Mastectomy in a Tertiary Care Center in Lahore, Pakistan
}

\author{
Usman Ali Rahman ${ }^{1}$, Khalil Ahmad ${ }^{2}$, Umair Nazir ${ }^{3}$, Shabbar Hussain Changazi ${ }^{4}$, Ayesha Choudary ${ }^{4}$, Qamar \\ Ashfaq Ahmad ${ }^{5}$ \\ ${ }^{1}$ Associate Professor, Department of Surgery, Al-Aleem Medical College, Lahore, Punjab Pakistan \\ ${ }^{2}$ Professor, Department of Surgery, Al-Aleem Medical College, Lahore, Punjab Pakistan \\ ${ }^{3}$ Operation Theatre Technologist, Gulab Devi Hospital, Lahore, Punjab Pakistan \\ ${ }^{4}$ Assistant Professor, Department of Surgery, Services Institute of Medical Sciences, Lahore, Punjab Pakistan \\ ${ }^{5}$ Associate Professor, Department of Surgery, Services Institute of Medical Sciences, Lahore, Punjab Pakistan
}

\section{ABSTRACT}

Background: Modified radical mastectomy (MRM) remains the mainstay of breast cancer surgery in under-developed countries like Pakistan as it reduces the morbidity and mortality associated with radical surgery. This study aims to delineate the clinicopathological findings and postoperative outcomes of patients undergoing modified radical mastectomy for breast carcinoma in a local setting.

Material and Methods: This cross-sectional study was conducted in Gulab Devi hospital Lahore, Punjab Pakistan, from January 2016 to December 2019. Patients $(n=70)$ with carcinoma breast planned for modified radical mastectomy were included in the study. Two suction drains were placed (in the axilla and under the flap) and removed when drainage was less than $30 \mathrm{cc}$ in 24 hours. The patients were followed-up weekly for one month and then at monthly intervals for up to one year. Independent t-test and chi-square test were used to study associations between different variables. A $P$ value less than .05 was considered statistically significant.

Results: The mean age of the patients was $48.43 \pm 12.3$ years. Most of the patients $(42.86 \%)$ had stage-II, grade-I carcinoma (50\%) with invasive ductal carcinoma as the most frequent histological variety (80\%). Majority of the patients ( $n=60 ; 85.57 \%$ ) were ER/PR positive. Mean duration of surgery was $124.8 \pm 20.33$ minutes, the mean duration of placement of drains was 3.5 \pm 4.5 days, and the mean length of hospital stay was $4.67 \pm 1.07$ days. Most common complications of mastectomy were wound infection (23.57\%) and seroma formation (20\%). Six patients (8.57\%) developed recurrence of disease in one year follow-up. Neoadjuvant chemotherapy increased the mean duration of surgery and drains placement $(P<.05)$ but had no effect on mean hospital stay and complications associated with surgery $(P>05)$.

Conclusions: Grade-I invasive ductal carcinoma with ER/PR positive receptor status was the most frequent variety of breast carcinoma. Neoadjuvant chemotherapy was associated with increased operative time and increased duration of drain placement.

Key words: Breast carcinoma, Complications, Modified radical mastectomy, Neoadjuvant chemotherapy.

Authors' Contribution:
${ }^{1}$ Conception; Literature research;
manuscript design and drafting; ${ }^{2,3}$ Critical
analysis and manuscript review; ${ }^{4,5}$ Data
analysis; Manuscript Editing.

Cite this article. Rahman U A, Ahmad K, Nazir U, Changazi S H, Choudary A, Ahmad Q A. Evaluation of Clinicopathological Findings and Postoperative Outcomes of Modified Radical Mastectomy in a Tertiary Care Center in Lahore, Pakistan. J Islamabad Med Dental Coll. 2021; 10(2): 89-94. Doi: 10.35787/jimdc.v10i2.634

$\begin{array}{ll}\text { Correspondence: } & \text { Article info: } \\ \text { Shabbar Hussain Changazi } & \text { Received: November 18, } 2020 \\ \text { Email: shabbarchangazi246@gmail.com } & \text { Accepted: June 14, 2021 }\end{array}$

Accepted: June 14, 2021

\author{
Funding Source: Nil \\ Conflict of Interest: Nil
}




\section{Introduction}

The mainstay for the treatment of breast carcinoma is mastectomy. Initially, radical mastectomy that removes pectoralis major muscle along with breast tissue is regarded as the standard management of breast carcinoma. ${ }^{1}$ However, this operation is associated with high morbidity and poor cosmesis. Modified radical mastectomy (MRM) was devised to address these issues. In this technique, pectoralis major muscle is left intact while breast tissue and the associated axillary lymph nodes are removed. This technique gained popularity as it was as efficacious as radical surgery, and morbidity was markedly decreased in MRM. ${ }^{2}$ With further advancement in breast surgery, breast-conserving therapy showed similar results in terms of morbidity and disfigurement. However, there are certain limitations for breast conservation therapy such as locally advanced disease and contraindications for radiotherapy, etc. ${ }^{3-6}$

MRM usually follows an uneventful recovery. Complications after MRM can be minimized with proper preoperative assessment, meticulous dissection, absolute hemostasis, and tension-free wound closure. In addition to the standard oncologic evaluation, preoperative evaluation includes an assessment of the patient's overall physiologic status, with specific consideration on the tolerability of anesthesia, uncontrolled diabetes, hypertension, anemia, or coagulopathy. Complications of modified radical mastectomy include seroma formation, wound infection and dehiscence, skin flap necrosis, hematoma formation, paresthesia of the arm along its medial aspect and lymphedema (late complication)..$^{7-9}$

MRM remains the mainstay of breast cancer surgery in under-developed countries like Pakistan. This is attributed to several reasons including the advanced stage at presentation, the lack of timely access to high-quality investigations, unaffordable cancer treatment, limited access to radiotherapy, and the lack of training in breast conservation surgery. ${ }^{10,11}$ The goal of this study was to evaluate the different stages, grades, and histological types of breast cancer and complications and outcomes of mastectomy with axillary clearance performed in a four-year period, in a local setting.

\section{Material and Methods}

This cross-sectional study was conducted from January 2016 to December 2019 in Gulab Devi Hospital Lahore, Punjab Pakistan. Approval was obtained from the Institutional Review Board of AlAleem Medical College/ Gulab Devi Hospital Lahore, Punjab Pakistan. A sample size of 70 patients was calculated with WHO calculator at $80 \%$ confidence level, $5 \%$ margin of error, using $12 \%$ expected percentage of breast cancer. ${ }^{12}$ Patients presenting with carcinoma breast and planned for modified radical mastectomy were included in the study through non-probability consecutive sampling method. Informed consent was taken. Patients with metastatic disease, uncontrolled diabetes mellitus, and uncompensated liver disease were excluded from the study. For diagnosis of disease, core needle biopsy of breast mass was done. Staging tests included ultrasound abdomen, CT scan of the chest and bone scan. Patients with locally advanced breast cancer (stage-III) underwent neoadjuvant chemotherapy before surgery. All patients having breast carcinoma underwent modified radical mastectomy with axillary clearance up to level II. Two suction drains were placed: one in the axilla and the other under the flap. Hemostasis was secured by diathermy and sutures. Suction drains were removed when drainage was less than $30 \mathrm{cc}$ in 24 hours. The patients were advised to follow up 
weekly for one month and then at monthly intervals for up to one year.

Data was statistically analyzed using SPSS v.21. Categorical variables like the stage of the disease, grade of disease, histological type, complications of the surgery, and recurrence of disease were presented as frequencies and percentages. Continuous variables including age, time of surgery, duration of the drain, and hospital stay were analyzed as mean with standard deviation. Association of neoadjuvant chemotherapy with duration of surgery, duration of the drain, and hospital stay was analyzed using independent t-test. The association of neoadjuvant chemotherapy with surgical complications was compared using chisquare test. A $P$-value of less than .05 was considered statistically significant.

\section{Results}

Out of 70 patients, 66 (94.29\%) were married with a mean age of $48.43 \pm 12.3$ years. Most of the patients had stage-II disease (42.86\%). Highly differentiated carcinoma was most prevalent $(50 \%)$ and invasive ductal carcinoma was most frequent histological variety $(80 \%)$ of carcinoma. Majority of patients with breast carcinoma had ER/PR positive (85.71\%) receptor status (Table I). Twenty-one (30\%) patients had neoadjuvant chemotherapy.

The mean duration of surgery was $124.8 \pm 20.33$ minutes. Suction drains were left in the axilla and under the flap for a mean duration of $3.5 \pm 4.5$ days ranging from 3 to 6 days. Wound infection was the most frequent complication of surgery $(28.75 \%)$ followed by seroma formation (20\%). Only 6 (8.57\%) patients developed recurrence of disease in oneyear follow-up (Table II). The mean hospital stay of all patients was $4.67 \pm 1.07$ days. We did not report any death during the 30-days follow-up.

\begin{tabular}{|c|c|c|}
\hline \multicolumn{3}{|c|}{$\begin{array}{l}\text { Table I: Characteristics of patients presenting with } \\
\text { breast carcinoma }(n=70)\end{array}$} \\
\hline \multicolumn{2}{|l|}{ Variables } & $n(\%)$ \\
\hline \multirow{4}{*}{ Stage } & Stage-Tis & $1(1.43)$ \\
\hline & Stage-I & $18(25.71)$ \\
\hline & Stage-II & $30(42.86)$ \\
\hline & Stage-III & $21(30)$ \\
\hline \multirow{3}{*}{ Grade } & Grade-I & $35(50)$ \\
\hline & Grade-II & $20(28.57)$ \\
\hline & Grade-III & $15(21.43)$ \\
\hline \multirow{5}{*}{$\begin{array}{l}\text { Histological } \\
\text { Type }\end{array}$} & $\begin{array}{l}\text { Ductal carcinoma in } \\
\text { situ }\end{array}$ & $1(1.43)$ \\
\hline & $\begin{array}{l}\text { Invasive ductal } \\
\text { carcinoma }\end{array}$ & $56(80)$ \\
\hline & $\begin{array}{l}\text { Invasive lobular } \\
\text { carcinoma }\end{array}$ & $10(14.28)$ \\
\hline & Medullary carcinoma & $2(2.85)$ \\
\hline & Mucinous Carcinoma & $1(1.43)$ \\
\hline \multirow{3}{*}{$\begin{array}{l}\text { Receptor } \\
\text { Status }\end{array}$} & ER & $60(85.71)$ \\
\hline & PR & $60(85.71)$ \\
\hline & HER2/neu & $20(28.57)$ \\
\hline
\end{tabular}

\begin{tabular}{|c|c|}
\hline Variables & n (\%) \\
\hline Seroma & $14(20)$ \\
\hline Wound infection & $20(28.57)$ \\
\hline Flap necrosis & $3(4.28)$ \\
\hline Respiratory Tract Infection & $2(2.85)$ \\
\hline Recurrence & $6(8.57)$ \\
\hline
\end{tabular}

Only $21 / 70$ (30\%) patients received neoadjuvant chemotherapy. Mean duration of surgery was significantly decreased in patients receiving neoadjuvant chemotherapy with an increase in mean duration of drain(s) placement $(P<.001)$. However neoadjuvant chemotherapy had no effect on mean hospital stay (Table III). The association of neoadjuvant chemotherapy with surgical complications was statistically insignificant (Table IV). 


\begin{tabular}{|c|c|c|c|}
\hline \multicolumn{4}{|c|}{$\begin{array}{l}\text { Table III: Association of neoadjuvant chemotherapy } \\
\text { with mean duration of surgery, duration of the drain } \\
\text { and hospital stay }\end{array}$} \\
\hline \multirow{2}{*}{$\begin{array}{l}\text { Mean } \\
\text { Duration }\end{array}$} & \multicolumn{2}{|c|}{ Neoadjuvant Chemotherapy } & \multirow{2}{*}{$\begin{array}{c}P \text { - } \\
\text { value }\end{array}$} \\
\hline & $\begin{array}{c}\text { Yes } \\
(n=21)\end{array}$ & $\begin{array}{c}\text { No } \\
(n=49)\end{array}$ & \\
\hline $\begin{array}{l}\text { Surgery } \\
\text { (minutes) }\end{array}$ & $100.30 \pm 12.20$ & $149.32 \pm 25.46$ & .001 \\
\hline $\begin{array}{l}\text { Drain } \\
\text { placement } \\
\text { (days) }\end{array}$ & $4.43 \pm 0.87$ & $3.59 \pm 0.93$ & .001 \\
\hline $\begin{array}{l}\text { Hospital } \\
\text { stay (days) }\end{array}$ & $4.71 \pm 1.08$ & $4.57 \pm 1.07$ & .143 \\
\hline
\end{tabular}

$* P<.05$ was considered as statistically significant

Table IV: Association of neoadjuvant chemotherapy with surgical complications $(n=70)$

\begin{tabular}{|c|c|c|c|c|}
\hline \multirow{2}{*}{\multicolumn{2}{|c|}{ Complications }} & \multicolumn{2}{|c|}{$\begin{array}{l}\text { Neoadjuvant } \\
\text { Chemotherapy }\end{array}$} & \multirow{2}{*}{$P$-value ${ }^{*}$} \\
\hline & & $\begin{array}{c}\text { Yes } \\
(n=21)\end{array}$ & $\begin{array}{c}\text { No } \\
(n=49)\end{array}$ & \\
\hline \multirow{2}{*}{ Seroma } & Yes & 3 & 11 & \multirow{2}{*}{.529} \\
\hline & No & 18 & 38 & \\
\hline \multirow{2}{*}{$\begin{array}{l}\text { Wound } \\
\text { Infection }\end{array}$} & Yes & 7 & 13 & \multirow{2}{*}{.564} \\
\hline & No & 14 & 36 & \\
\hline \multirow{2}{*}{$\begin{array}{l}\text { Flap } \\
\text { necrosis }\end{array}$} & Yes & 2 & 1 & \multirow{2}{*}{.432} \\
\hline & No & 19 & 48 & \\
\hline \multirow{2}{*}{$\begin{array}{l}\text { Respiratory } \\
\text { infection }\end{array}$} & Yes & 1 & 1 & \multirow{2}{*}{.732} \\
\hline & No & 20 & 48 & \\
\hline
\end{tabular}

$* P<.05$ was considered as statistically significant

\section{Discussion}

Modified radical mastectomy with axillary clearance is the most common surgical procedure performed for cancer of the breast. In this study, the mean age of patients was significantly lower than other studies. ${ }^{13,14}$ This is an alarming sign and depicts the early occurrence of breast carcinoma in the local population. We report a mean duration of 3.67 days for drain placement and 4.67 days for hospital stay, respectively. However, a study conducted by Karwasra et al. ${ }^{14}$ showed increased mean durations for drain (9.22 days) and hospital stay (9.22 days). Okada et al. ${ }^{15}$ reported mean hospital stay of 7 days. These results had higher mean duration of drain and mean hospital stay as compared to the present study. This may due to more meticulous dissection and heavy patient load leading to refinement of operative skills.

In this study $14(20 \%)$ patients developed seroma and 20 (20.87\%) patients developed wound infection. Karwasra and colleagues ${ }^{14}$ conducted a study in Rohtak, India with a sample of seventy-five patients and documented that 11 (14.67\%) patients developed wound infection, which is higher as compared to our study. Similarly, Dahri and colleagues $^{16}$ conducted a study in Nawab Shah, Sindh Pakistan on 150 patients. According to their study wound infection was seen in 15 (10\%) patients, seroma formation in $50(33.3 \%)$ and wound dehiscence in 2 (1.3\%) patients, respectively. Decreased rate of postoperative complications, especially seroma formation and wound infection were due to improved surgical techniques i.e., proper skin flap harvesting, absolute hemostasis, obliteration of dead space, tensionless skin closure, early physiotherapy of arm on operative side, and removal of the drain after it had remained empty for 24 hours.

Our study demonstrated that neoadjuvant chemotherapy significantly increased the mean duration of surgery and the mean duration of the drain placement. These findings are in concordance with studies conducted by Gümüş et al. ${ }^{17}$ and Uslukaya et al. ${ }^{18}$ Both these studies reported increased mean duration of surgery and mean duration of drain in patients who underwent neoadjuvant chemotherapy. They also reported increased length of hospital stay with neoadjuvant chemotherapy. In our study neoadjuvant chemotherapy had no effect on mean hospital stay and complications associated with surgery. This may be because patients were discharged and sent home with the drain. Patients were advised to come to the outpatient department, once there was minimal addition in the drain. Finally, this study depicted that 
neoadjuvant chemotherapy was not associated with an increased risk of postoperative complications. Similar results were also shown by studies conducted by Adamson et al. ${ }^{19}$ and Decker et al. ${ }^{20}$ irrespective of the chemotherapeutic drugs used for treatment.

\section{Conclusion}

Grade-I invasive ductal carcinoma with ER/PR positive receptor status was the most frequent variety of breast carcinoma. Neoadjuvant chemotherapy was associated with increased operative time and increased duration of drain placement.

\section{References}

1. Freeman MD, Gopman JM, Salzberg CA. The evolution of mastectomy surgical technique: from mutilation to medicine. Gland Surg. 2018; 7(3): 308. Doi: 10.21037/gs.2017.09.07.

2. Lumachi F, Brandes AA, Burelli P, Basso SM, lacobone $M$, Ermani $M$. Seroma prevention following axillary dissection in patients with breast cancer by using ultrasound scissors: a prospective clinical study. J Eur Surg Oncol. 2004; 30(5): 526-30. Doi: 10.1016/j.ejso.2004.03.003.

3. Arndt V, Stegmaier C, Ziegler H, Brenner H. Quality of life over 5 years in women with breast cancer after breast-conserving therapy versus mastectomy: a population-based study. J Cancer Res Clin Oncol. 2008; 134(12): 1311. Doi: 10.1007/s00432-008-0418$y$.

4. Vrouwe SQ, Somogyi RB, Snell L, McMillan C, Vesprini D, Lipa JE. Patient-reported outcomes following breast conservation therapy and barriers to referral for partial breast reconstruction. Plast Reconstr Surg. 2018; 141(1): 1-9. Doi: 10.1097/PRS.0000000000003914.

5. Thiessen FE, Tjalma WA, Tondu T. Breast reconstruction after breast conservation therapy for breast cancer. Eur J Obstet Gynecol Reprod Biol. 2018; 230: 233-8. Doi: 10.1016/j.ejogrb.2018.03.049.

6. Fang $M$, Zhang $X$, Zhang $H$, Wu K, Yu Y, Sheng Y. Local control of breast conservation therapy versus mastectomy in multifocal or multicentric breast cancer: a systematic review and meta-analysis. Breast Care. 2019; 14(4): 188-93. Doi: 10.1159/000499439.
7. Shaikh BF, Memon AA, Kumar M, Memon Z, Soomro E. Complications of modified radical mastectomy in carcinoma breast patients. Med Channel. 2014; 20(1).

8. Rana AM, Ahmed SU, Alam F, Joardar Al, Chowdhury $A K$, Bari MA, et al. Electrosurgery dissection versus sharp dissection: effect on early postoperative wound complications in modified radical mastectomy. MMJ. 2019; 28(3): 634-40. PMID: 31391437.

9. Abass MO, Gismalla MD, Alsheikh AA, Elhassan MM. Axillary lymph node dissection for breast cancer: Efficacy and complication in developing countries. J Glob Oncol. 2018; 4: 1-8. Doi: 10.1200/JGO.18.00080.

10. Cleary J., Gelband H., Wagner J. Cancer: Disease Control Priorities. 3rd ed. Washington, DC: World Bank; 2015; p. 320-63.

11. Barton $M B$, Frommer $M$, Shafiq J. Role of radiotherapy in cancer control in low-income and middle-income countries. Lancet Oncol. 2006; 7(7): 584-95. Doi: 10.1016/S1470-2045(06)70759-8.

12. Bray F, Ferlay J, Soerjomataram I, Siegel RL, Torre LA, Jemal A. Global cancer statistics 2018: GLOBOCAN estimates of incidence and mortality worldwide for 36 cancers in 185 countries. CA: Cancer J Clin. 2018; 68(6): 394-424. Doi: 10.3322/caac.21492.

13. Menhas R, Umer S. Breast Cancer among Pakistani Women. Iran J Public Health. 2015: 586-7. PMID: 26056679.

14. Karwasra RK, Srivastava S, Parshad S, Tripathi M, Arora B. A prospective randomized study on management of suction drains in patients undergoing modified radical mastectomy. IJERMDC. 2015; 2(11): 9-19. ISSN: 2349-1590

15. Okada N, Narita Y, Takada M, Kato H, Ambo Y, Nakamura $F$, et al. Early removal of drains and the incidence of seroma after breast surgery. Breast Cancer. 2015; 22(1): 79-83. Doi: 10.1007/s12282013-0457-3.

16. Dahri FJ, Awan MS, Qazi AR, Khaskheli NM, Soomro IA. Early wound complications following modified radical mastectomy with axillary clearance. J Surg Pak. 2011; 16:4.

17. Gümüş $M$, Satıcı Ö, Ülger BV, Oğuz A, Taşkesen F, Girgin S. Factors affecting the postsurgical length of hospital stay in patients with breast cancer. J Breast Health. 2015; 11(3): $128 . \quad$ Doi: 10.5152/tjbh.2015.2546.

18. Uslukaya Ö, Türkoğlu A, Gümüş $M$, Bozdağ Z, Yılmaz $A, G u ̈ m u ̈ s ̧ ~ H$, et al. Factors that Affect Drain Indwelling Time after Breast Cancer Surgery. J Breast Health. 2016; 12(3): 102. Doi: 10.5152/tjbh.2016.3070. 
19. Adamson K, Chavez-MacGregor M, Caudle A, Smith B, Baumann D, Liu J, et al. Neoadjuvant hemotherapy does not increase complications in oncoplastic breast-conserving surgery. Annals Surg Oncol. 2019; 26(9): 2730-7. Doi: 10.1245/s10434-019-07408-6.
20. Decker MR, Greenblatt DY, Havlena J, Wilke LG, Greenberg CC, Neuman HB. Impact of neoadjuvant chemotherapy on wound complications after breast surgery. Surgery. 2012; 152(3): 382-8. Doi: 10.1016/j.surg.2012.05.001. 